\title{
NEOGENE HISTORY OF THE SOUTH PACIFIC TRADEWINDS: EVIDENCE FOR HEMISPHERICAL ASYMMETRY OF ATMOSPHERIC CIRCULATION
}

\author{
DAVID K REA and MAURICE K BLOOMSTINE
}

Oceanography Program, Department of Atmospheric and Oceanic Sclence, The Unlversity of Michigan, Ann Arbor, Michigan 48109 (US A)

(Received March 13, 1985, revised and accepted October 24, 1985)

\section{ABSTRACT}

Rea, D K and Bloomstıne, M K, 1986 Neogene history of the South Pacifıc tradewinds evidence for hemispherical asymmetry of atmospheric circulation Palaeogeogr, Palaeochmatol, Palaeoecol , 55 55-64

Eolıan dust grains extracted from southeast Pacific pelagıc sediments provide a Neogene record of southern hemisphere atmospheric processes The mass accumulation rate of dust has been low and generally constant at $1-4 \mathrm{mg} / \mathrm{cm}^{2} 10^{3}$ y since the late Olıgocene Eolian grainsize data show an increase from $82 \phi(340 \mu)$ in older sediments to $72 \phi(680 \mu)$ in younger material This shift occurred about $105 \mathrm{~m} \mathrm{y}$ ago and reflects a significant increase in the intensity of atmospheric circulation then There is no obvious response to the onset of northern hemisphere glaciation $25 \mathrm{~m}$ y ago in these eolian records from the South Pacific Comparison with existing information from the northern hemisphere suggests that the southern hemisphere has had more intense atmospheric circulation throughout the Neogene and that this asymmetry reached its greatest extent between 105 and $25 \mathrm{Ma}$

\section{INTRODUCTION}

The present average temperature differential, in the mid-troposphere, between the equator and the north pole is $273^{\circ}$, from the equator to the south pole it is $391^{\circ}$, a difference of nearly $12{ }^{\circ} \mathrm{C}$ (Flohn, 1981a) This enhanced temperature gradient in the southern hemisphere is responsible for more intense atmospheric circulation, a broader zone of westerlies, and the northward shift of the intertropical convergence zone to its average position of about $6^{\circ} \mathrm{N}$ (Barry and Chorley, 1976, Flohn, 1981a, b)

The Cenozoic history of polar cooling (Kennett, 1977, 1982, Frakes, 1979) indicates that a similar or greater thermal asymmetry, and therefore an asymmetry in atmospheric curculation, has existed since at least the beginning of ice bulld-up on Antarctica at $38 \mathrm{Ma}$ Further development of the Antarctic ice sheet at $12-13 \mathrm{Ma}$ (Woodruff et al, 1981) and again at about $6 \mathrm{Ma}$ (Kennett, 1977) may have increased the temperature differences between the poles The onset of northern hemisphere glaciation at $25 \mathrm{Ma}$ 
(Shackleton et al, 1984) may have reduced the early Pliocene thermal asymmetry significantly. Flohn $(1981 \mathrm{a}$, b) estimates the mid-Miocene to mid-Pliocene temperature difference at the poles to be similar to that for the height of Austral winter now, with the south pole about $27^{\circ}$ colder than the north, relatively much stronger southern hemisphere crrculation, and the intertropical convergence zone situated at $10^{\circ}-12^{\circ} \mathrm{N}$

These concepts of past atmospheric curculation appear well-founded, have an important bearing on our understanding of past oceanic circulation, especially upwelling, but have not been tested with direct geological evidence Our work with the record provided by eolian dust deposited in the ocean now permits such a direct evaluation of past atmospheric circulation (Rea et al , 1985)

\section{Eolian deposition, prior work and the present effort}

Dust lifted from the continents and carried to the deep sea by the zonal winds forms a minor percentage of most pelagic sediments It is possible to extract that dust from the bulk sediment and use it to construct a record of atmospheric processes The mass flux of dust, or supply, varies with the aridity of the eolian source area (Rea and Janecek, 1981a, Rea et al , 1985), and the grainsize of the dust that has been carried $2000 \mathrm{~km}$ or more downwind provides a record of the intensity of the transporting winds, stronger winds carry coarser grains (Parkin, 1974, Janecek and Rea, 1985)

Two North Pacific cores have provided records of eolian deposition that span the entire Cenozoic, piston core LL44-GPC3 from $303^{\circ} \mathrm{N}, 1578^{\circ} \mathrm{W}$ (Janecek and Rea, 1983), and DSDP Hole 576 from $324{ }^{\circ} \mathrm{N}, 1643^{\circ} \mathrm{E}$ (Janecek, 1985) These two cores, about $3600 \mathrm{~km}$ apart, have very similar records which indicate, by increasing grainsize, increasing intensity of atmospheric circulation throughout the Neogene Increases appear gradiational in the Miocene, but the Pliocene increase may be more sudden (Rea et al, 1985) Another study examined the late Miocene to Pleistocene record of eolian deposition in five North Pacific cores from both the tradewinds and the westerlies Results of that work showed a moderate increase in eolian grainsize and a five-fold increase in the flux of dust to the North Pacific during the mid-Plocene (Rea and Janecek, 1982) Stein and Robert (1986) have reported on eolian deposition beneath the southern hemisphere westerlies just east of Australıa Their data reflect the increasing aridity of Australia during the Neogene, but show little change in the grainsize of the land-derived minerals

Leg 92 of the Deep Sea Drilling Project drilled a series of holes across the west flank of the East Pacific Rise along $19^{\circ} \mathrm{S}$ Nearly undisturbed sedıments were recovered with the hydraulic piston corer, and the sections together provide a record of the past $285 \mathrm{Ma}$ (Leinen et al, 1986) Here we present the eolian data from three of those sites, 597, 598, and 601 (F1g 1) in order to examine the record of southern hemisphere atmospheric processes 


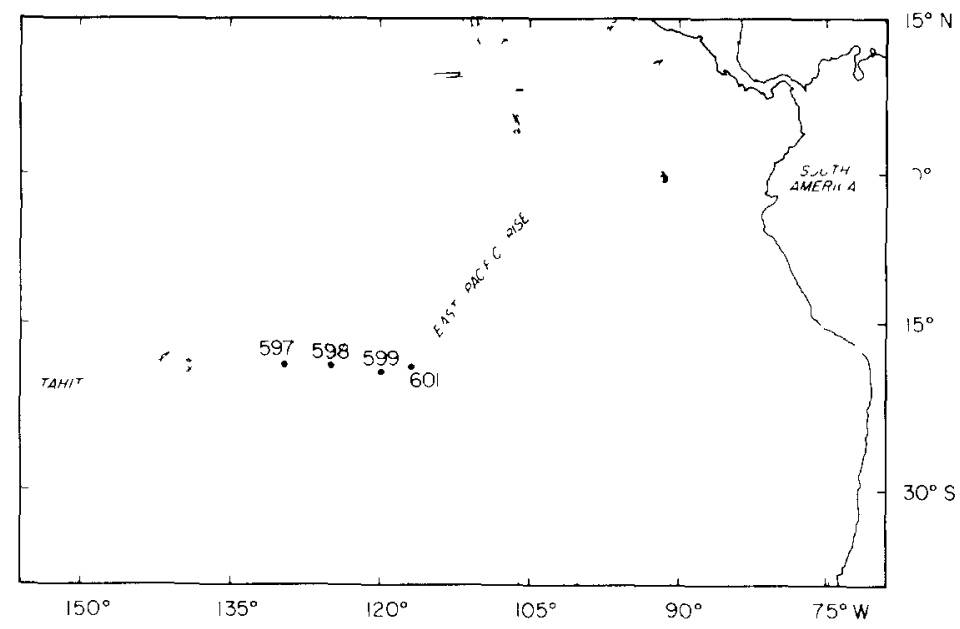

Fig 1 Index map of the South Pacific showing Leg 92 drillsites

The record of polar ice accumulation suggests that increases in the intensity of the zonal winds would be expected in the mid-Miocene and possibly in the late Miocene as well As the atmospheric circulation of the hemispheres may be generally independent, it is not clear what response to the onset of northern hemisphere glaciation would be expected in the southern hemisphere record Dust flux measurements from the Leg 92 drillsites should also provide a Neogene record of the climate of the South American source region Finally, comparison of the southern hemisphere eolian record with the information previously determined for the northern hemisphere should enable us to come to some understanding of the nature of the hemispherical asymmetry in atmospheric circulation described by Flohn $(1981 \mathrm{a}, \mathrm{b})$

\section{Analytical methods and accuracy}

The data generated in our laboratory are the mass accumulation rate $(M A R)$ of the total eolian component which is nearly all quartz and clay minerals, dominantly llite, and the median grainsize $\left(\phi_{50}\right.$ of Folk, 1974) of that component The mineral component which, away from other sources of terrigenous material, represents eolian dust (Rea et al, 1985) is isolated by a series of extractions to remove the biogenous components, $\mathrm{CaCO}_{3}$ and opaline silica, and the authigenic (chemically formed) components, $\mathrm{Fe} / \mathrm{Mn}$ oxides and hydroxides and the zeolite minerals, of the sediment Detalls of this procedure are given by Rea and Janecek (1981b) Mass accumulation rates are the product of the linear sedimentation rate $(L S R)$ and dry bulk density $(D B D)$ of the sedıments $L S R\left(\mathrm{~cm} / 10^{3} \mathrm{y}\right) \times D B D\left(\mathrm{~g} / \mathrm{cm}^{3}\right)=M A R$ $\left(\mathrm{g} / \mathrm{cm}^{2} 10^{3} \mathrm{y}\right)$ The eolian $M A R$ is then the product of the total sediment $M A R$ and the weight percent of eolian materials Sediment ages and 
sedimentation rates are those reported by Leinen et al (1986) for the Leg 92 drillsites, all data are tabulated by Bloomstine and Rea (1986)

The accuracy of the eolian MAR data is difficult to determine and depends partly on the biostratigraphy and partly on the laboratory procedure The placement of biostratigraphic boundaries, the assumption of a constant linear sedimentation rate between boundaries, and the assignment of absolute ages to the boundaries combine to produce errors larger than a few percent Furthermore, the unusually low amount of eolian material in the southeast Pacific samples means that the small laboratory inaccuracies are relatively much larger than normal Some volcanic glass occurs in many of the samples and can not be completely removed by our extraction procedures These imprecisions in the data allow us to attach geological signiflcance to only the largest and most obvious $M A R$ changes, those in excess of a factor of two or three

The grainsize of the eolian component was determined on the $6-10 \phi$ $(16-1 \mu)$ size fraction at $033 \phi$ intervals using an electronic particle-size analyzer $\left[\phi=-\log _{2} D\right.$, where $D$ is the grain diameter in millimeters, approximate size equivalents are $10 \phi=1 \mu, 9 \phi=2 \mu, 8 \phi=4 \mu, 7 \phi=8 \mu$, etc ] The median grainsizes are an average of duplicate runs for each sample and have an estimated accuracy of $\pm 01 \phi$

We sampled the Leg 92 cores at approximately a $1 \mathrm{~m}$ interval Since linear sedimentation rates vary by two orders of magnitude, our plots of eolian $M A R$ and grainsize data versus sample age (Figs 2-6) show a large variation in sample spacing The apparent smoothing of the data in the younger, upper portions of Holes 597 and 598 should be considered an artifact of this sample spacing rather than a reflection of reality

\section{EOLIAN DEPOSITION IN THE SOUTHEAST PACIFIC}

Sedıments recovered during Leg 92 are a mixture of nannofossll ooze and clays Lesser amounts of foraminifers, zeolites, volcanic glass, palagonite and opaque grains also occur in the sedment (Leinen et al, 1986) Sed1ments range in age from late Oligocene $(285 \mathrm{Ma})$ to Pleistocene, with mass accumulation rates of the bulk sedıment ranging from a low of $5 \mathrm{mg} / \mathrm{cm}^{2}$ $10^{3} \mathrm{y}$ to a high of $1125 \mathrm{mg} / \mathrm{cm}^{2} 10^{3} \mathrm{y}$

Eolian MAR values at Hole 597 are extremely low for the past $17 \mathrm{Ma}$, generally less than $2 \mathrm{mg} / \mathrm{cm}^{2} 10^{3}$ y Between 17 and $19 \mathrm{Ma}$ a maximum in eolian accumulation occurs, in older materials the $M A R$ is again low, ranging from 1 to $5 \mathrm{mg} / \mathrm{cm}^{2} 10^{3}$ y Basal sediments contam a greater amount of mineral material (Fig 2) The gramsize of the eolian component averages about $81 \phi$ in the upper Oligocene and lower Miocene sedıments (Fig 3)

Sedıments at Hole 598 range in age from Plesstocene to early Miocene The MAR of the eolian component is generally low, about $3 \mathrm{mg} / \mathrm{cm}^{2} 10^{3} \mathrm{y}$, with a peak at about $8 \mathrm{Ma}$ (Fig 4) This apparent increase results from volcanic glass remaining in the samples after extraction. 

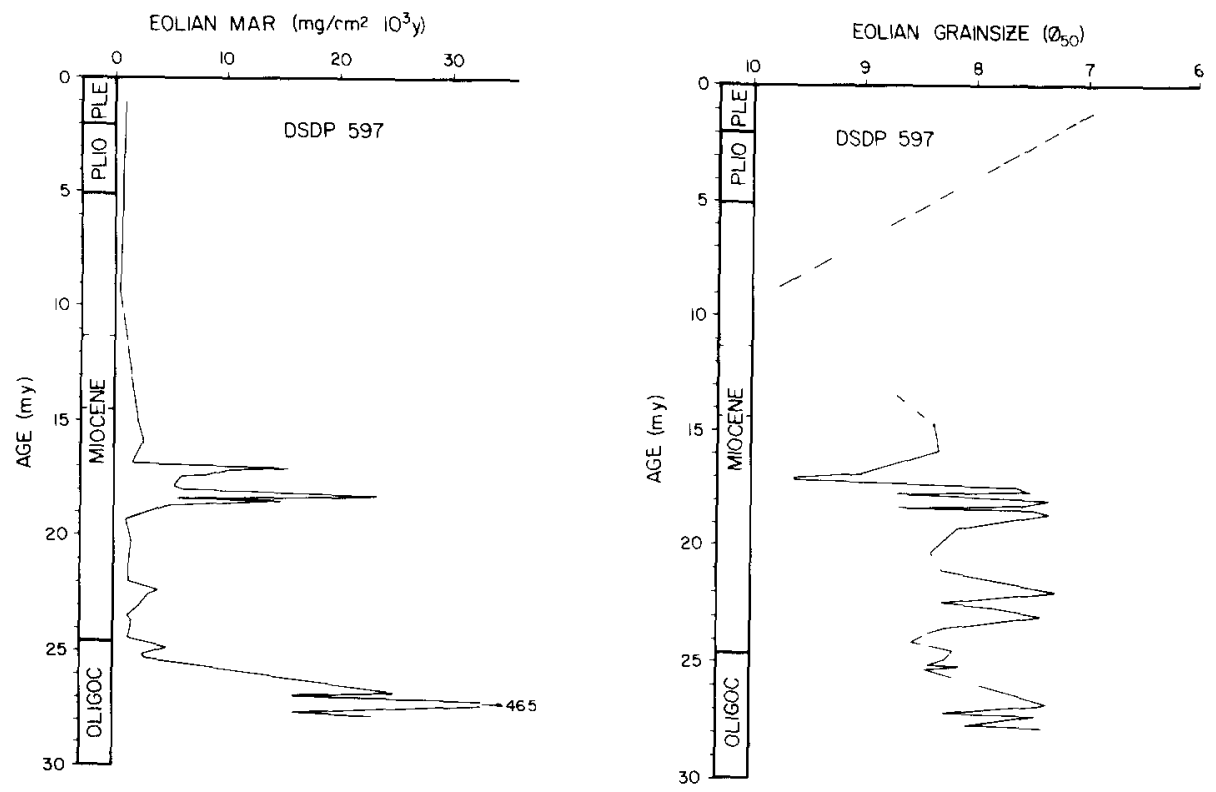

Fig 2 Mass accumulation rate of the eolian component of deep-sea sediments from DSDP Site 597

Fig 3 Grain size of eolian material at Site 597
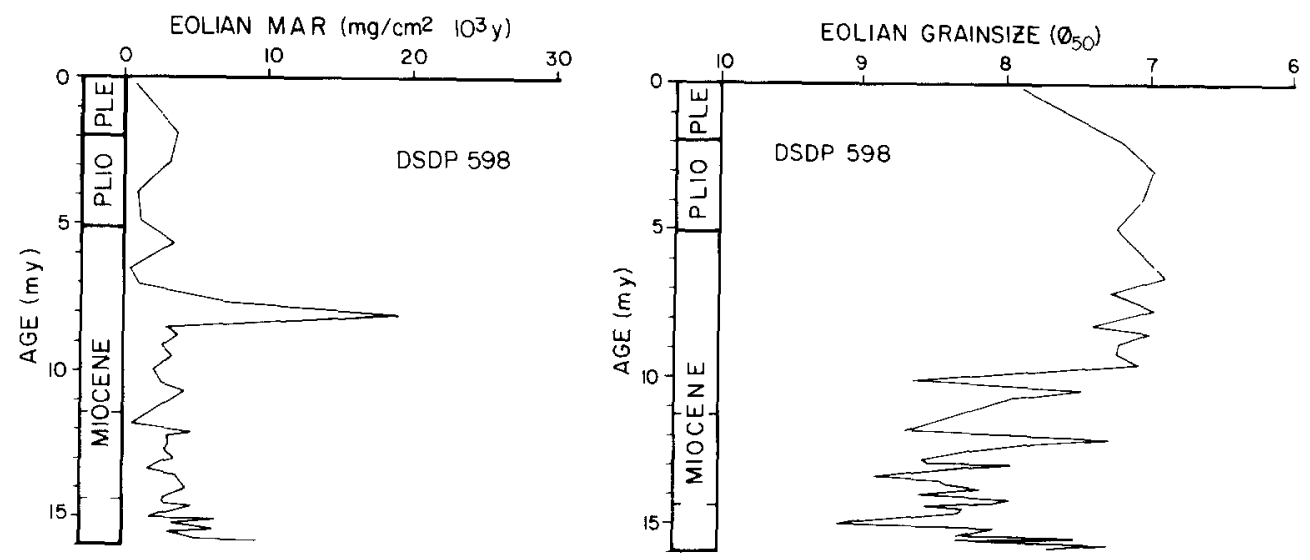

Fig 4 Mass accumulation rate of the eolian component of deep-sea sediments from DSDP Site 598

Fig 5 Grain size of eolian material at Site 598

Eolian grainsize data from Hole 598 exhibit the only distinct change in grainsize observed in all the Leg 92 sequences (Fig 5) The grainsize of the dust from sediment younger than $95 \mathrm{Ma}$ is about $72 \phi$ whereas sedıments older than $118 \mathrm{Ma}$ at this site have an average grain size of $82 \phi$ 


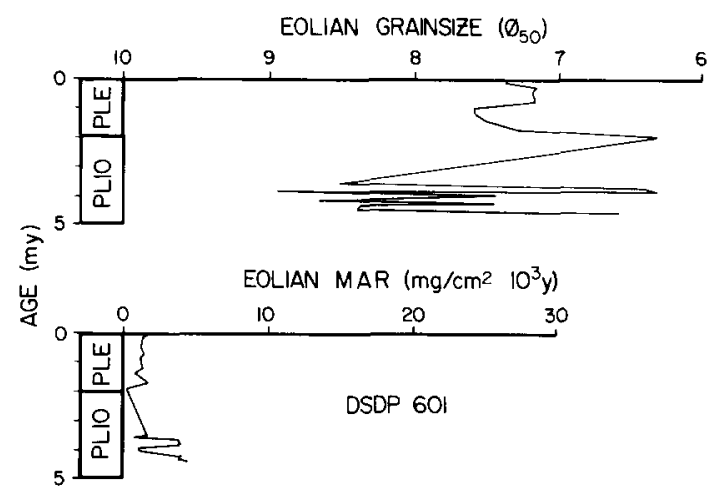

Fig 6 Mass accumulation rate and grainsize of the eohan component of deep-sea sediments from DSDP Site 601

Hole 601 recovered sediments ranging in age from Pleistocene to early Pliocene The MAR of the eolian component at this site is $1-2 \mathrm{mg} / \mathrm{cm}^{2} 10^{3} \mathrm{y}$ (Fig 6) The eolian grainsize fluctuates widely about an average of $75 \phi$ which does not appear to change (Fig 6)

\section{IMPLICATIONS OF THE EOLIAN RECORD}

A striking characteristic observed at the sites examined from the Leg 92 transect is the low and constant flux of eolian dust carried by the tradewinds into the deep-sea during the past $285 \mathrm{~m} \mathrm{y}$ The flux of dust to the South Pacific has been about $1-4 \mathrm{mg} / \mathrm{cm}^{2} 10^{3} \mathrm{y}$, an order of magnitude less than fluxes beneath the North Pacific tradewinds (Rea, 1982, Rea and Janecek, 1982) and two orders of magnitude less than those of the northern hemisphere westerlies (Rea et al , 1985) The eolian MAR values in the South Pacific indicate no increase in flux corresponding to either the growth of the Antarctic ice sheet at about 12-13 Ma ago or the onset of northern hem1sphere glaciation at 2.5 Ma This low and constant flux may record a consistently humid and vegetated source region in South America Furthermore, it is likely that orographic precipitation on the east flank of the Andes has always been an effective removal mechanism for any dust carried by the wind across South America

The eolian grainsize data indicate a single primary shift which occurs at Hole 598 between $118 \mathrm{Ma}$ and $95 \mathrm{Ma}$, from grains averaging $82 \phi$ in older sediments to $72 \phi$ in the younger sediments Unfortunately the grainsize change at about $105 \mathrm{Ma}$ is not recorded either at Hole 599 where basement age is about $8 \mathrm{Ma}$ or at 597 where this interval is represented by slowlyaccumulating pelagic clay, and, therefore, is essentially unsampled at our 1-m sampling interval However, the eolian grainsize of upper Oligocene to lower Miocene materials at Hole 597 averages $81 \phi$ and that from the upper Miocene to Pleistocene sediments at 599 is about $73 \phi$ (Bloomstine and Rea, 1986) so data from these other locations are consistent with the record at 598. 
The large increase in eolian grainsize that occurred at about $105 \mathrm{Ma}$ (Fig 5) implies a significant intensification in the southern hemisphere tradewinds then The size change occurs in foraminiferal zones N14 and N15 (see Kennett and Srmivasan, 1983), approximately 2 Ma younger than the shift in the oxygen-1sotope values which is taken to record the bulld-up of ice in Antarctica (zones N10-N12, Woodruff et al, 1981)

Two other types of paleoceanographic information show important changes during the middle to late Miocene The recently compiled history of the calcium carbonate compensation depth and lysocline in the South Pacific reveals the formation of a 600-m thick lysocline zone at a time coincident with Antarctic ice growth (Rea and Leinen, 1985) The formation of a lysocline distinctly shallower than the compensation depth may be the result of increased surface water productivity in the oligotrophic sub-tropical gyre (Broecker and Peng, 1982), possibly caused by enhanced surface circulation If the southern hemisphere tradewinds control equatorial upwelling, then the record of deposition of biogenic opal in the equatorial region should provide some indication of intensification of both those phenomena Leinen (1979) showed an increase in opal deposition in the equatorial Pacific that began about $15 \mathrm{Ma}$ and reached a maximum 8-10 $\mathrm{Ma}$ and suggested that this event recorded an intensification of the southeast tradewinds Our eolian data are consistent with that suggestion and the tımıng

Together, these data imply a time lag on the order of two to three milhon years between Antarctic ice accumulation and the beginning of productivity enhancement and the later increase in atmospheric circulation intensity and equatorial productivity maximum The fact that atmospheric circulation intensity increased only after the ice build-up was largely complete may imply that polar refrigeration continued or possibly even intensified after the high-albedo snow and ice cover was established on Antarctica

The late Miocene and Plio-Pleistocene portion of the eolian grainsize record shows no indication of a significant, enduring shift in wind intensity (Figs 5 and 6) We interpret this negative evidence to indicate little additional polar cooling during the Messinian ice build-up at about $6 \mathrm{Ma}$, and no significant intensification of the southern hemisphere tradewinds in response to the onset of northern hemisphere glaciation This last conclusion, although consistent with the results of Stein and Robert (1986, fig 10), entals numerous paleoceanographic ramifications and in considering it, the reader should bear in mind the relatively crude nature of this particular data set

Comparison with northern hemisphere records of eolian processes shows the largest difference in the size of eolian grains between about 105 and $25 \mathrm{Ma}$ During the late Miocene and early Pliocene this size difference may be as much as $14 \phi, 72 \phi$ at DSDP Sites 598 and 601 (Figs 5 and 6 ) versus $86 \phi$ at northern hemisphere tradewind Sites 463 and 292 (Rea and Janecek, 1982) There are no lower Miocene records from the northern hemisphere tradewinds for comparison with the older portions of Sites 598 and 597, but eolian sediments of that age beneath the northern hemisphere westerlies have 
sizes of $86-90 \phi$ (Rea et al, 1985) versus about $82 \phi$ in the South Pacific tradewind cores There is approximately a $10 \phi$ difference in the size of Pleistocene eolian grains between the northern, $84 \phi$ (Rea, 1982, Rea and Janecek, 1982), and southern, $74 \phi$, tradewind systems

These data are not adequate for a comprehensive comparison of interhemisphere atmospheric circulation but do provide strong supporting evidence for Flohn's (1981a, b) concepts of a long-term asymmetry in hemispherical circulation reaching its extreme in the late Miocene and early Pliocene

\section{SUMMARY}

Eolian grains extracted from DSDP cores taken along a transect at $19^{\circ} \mathrm{S}$ in the southeast Pacific provide a Neogene record of southern hemisphere atmospheric processes That record shows a very low input of dust to the southeast Pacific, $1-4 \mathrm{mg} / \mathrm{cm}^{2} 10^{3} \mathrm{y}$, one to two orders of magnitude less than the northern hemisphere fluxes These low flux values may reflect both a continuously vegetated source region and continuing orographic precipitation on the east flank of the Andes cleansing any dust from the air

The size of the eolian grains becomes much coarser at about $105 \mathrm{Ma}$ Older grains have an average diameter of $82 \phi$, younger grains are about $72 \phi$ The coarsening is interpreted to be the result of an increase in the intensity of the southern hemisphere tradewinds at $105 \mathrm{Ma}$, approximately $2 \mathrm{Ma}$ later than the time of rapid ice accumulation on Antarctica The grainsize record shows no evidence of a significant response in southern hemlsphere circulation to either the Messinian ice accumulation event or the onset of northern hemisphere glaciation at $25 \mathrm{Ma}$

Comparison of the southern hemisphere eolian grainsize record with existing data from the North Pacific shows that southern hemisphere atmospheric curculation has been more intense than that of the northern hemlsphere throughout the Neogene As envisioned by Flohn (1981a, b), the asymmetry appears to have been most extreme between 105 and $25 \mathrm{Ma}$ when the earth was in an asymmetrical, unipolar glacial mode

\section{ACKNOWLEDGEMENTS}

An earler version of this report was reviewed by N G Pisias He made several helpful suggestions that improved the final version

\section{REFERENCES}

Barry, R G and Chorley, R J, 1976 Atmosphere, Weather and Clımate Methuen, London, $432 \mathrm{pp}$

Bloomstıne, M K and Rea, O K, 1986 Post-middle Olıgocene history of eolıan deposition from the southeast Pacific tradewinds In $M$ Leinen, D $\mathrm{K}$ Rea et al, Initial Reports of the Deep Sea Drillıng Project, Vol 92 U S Government Printing Office, Washington, D C , in press 
Broecker, W S and Peng, T H, 1982 Tracers in the Sea Lamont-Doherty Geol Obs, Palısades, N Y, $690 \mathrm{pp}$

Flohn, H, 1981a Major Clımatıc Events Associated with a Prolonged $\mathrm{CO}_{2}$-induced Warming Inst for Energy Analysis, Oak Ridge, Tenn, $80 \mathrm{pp}$

Flohn, H, 1981b A hemispheric circulation asymmetry during late Tertiary, Geol Rundschau, 70 725-736

Folk, R L, 1974 Petrology of Sedımentary Rocks Hempthıll, Austın, Tes, 182 pp

Frakes, L A , 1979 Clımates Through Geologıc Time Elsevier, New York, N Y , 310 pp

Janecek, T R, 1985 Eolian sedimentation in the northwest Pacitic Ocean A preliminary examination of the data from Deep Sea Drilling Project Sites 576 and 578 In G R Heath, L Burckle et al, Initial Reports of the Deep Sea Drilling Project, Vol 86 U S Government Printing Office, Washington, D C , pp 589--603

Janecek, T R and Rea, D K, 1983 Eohian deposition un the northeast Pacific Ocean Cenozoic history of atmospheric circulation Geol Soc Am Bull , 94 730-738

Janecek, T R and Rea, D K, 1985 Quaternary tluctuations in the northern hem1. sphere tradewinds and westerlies Quat Res, 24 150-163

Kennett, J P, 1977 Cenozorc evolution of Antarctic glaciation, the circum Antarctic Ocean, and their impact on global paleoceanogiaphy $J$ Geophys Res, 82 $3843-3860$

Kennett, J P, 1982 Marıne Geology Prentice-Hall, Englewood Clıffs, N J, 813 pp

Kennett, J P and Srınıvasan, M S, 1983 Neogene Planktonıc Foramınifera, A Phylogenetic Atlas Hutchinson and Ross, Stroudsburg, $\mathrm{Pa}, 265 \mathrm{pp}$

Leinen, M, 1979 Biogenic silica accumulation in the central equatorial Pacific and its implications for Cenozoic paleoceanography Geol Soc Am Bull Part II, 90 $1310-1376$

Leinen, M, Rea, D K, et al, 1986 Initial Reports of the Deep Sea Drilling Project, Vol 92 U S Government Printing Otfice, Washington, D C, in press

Parkın, D W, 1974 Tradewinds during the glacial cycles Proc R Soc London, Sec A, $337 \quad 73-100$

Rea, D K, 1982 Fluctuation in eolian sedimentation during the past five glacialinterglacial cycles A preliminary examination of data from DSDP Site 503B, eastern Equatorial Pacific Ocean In J V Gardner, W L Prell et al, Initial Reports of the Deep Sea Drilling Project, Vol 68 U S Government Printıng Office, Washington, D C , pp $409-415$

Rea, D K and Janecek, T R, 1981a Late Cretaceous hıstory of eolian deposition in the Mid-Pacıfic Mountains, central North Pacıfic Ocean Palaeogeogr, Palaeoclimatol, Palaeoecol, $36 \quad 55-67$

Rea, D K and Janecek, T R, 1981b Mass accumulation rates of the non-authigenic, inorganic, crystallıne (eolıan) component of deep sea sediments from the western Mid-Pacific Mountains, DSDP Site 463 In J Thiede, $T$ L Vallier et al, Initial Reports of the Deep Sea Drilling Project, Vol 62 US Government Printing Oftice, Washington, D C , pp 653-659

Rea, D K and Janecek, T R, 1982 Late Cenozolc changes in atmospheric circulation deduced from North Pacific eolian sediments Mar Geol , 49 149-167

Rea, D K and Leinen, M, 1985 Neogene history of the calcite compensation depth and lysocline in the South Pacific Ocean Nature, 316 805-807

Rea, D K, Leinen, M and Janecek, T R, 1985 Geologic approdch to the long-term history of atmospheric circulation Science, $227 \quad 721-725$

Shackleton, N J, Backman, J, Zımmerman, H, Kent, D U, Hall, M A, Roberts, D G, Schnither, D, Baldauf, J G, Desprarries, A, Homılghausen, R, Huddlestun, P, Keene, J B, Kaltenback, A J, Krumsiek, K A O, Morton, A C, Murray, J W and Westberg-Smith, J, 1984 Oxygen isotope calibration of the onset of ice-rafting and history of glaciation in the North Atlantic region Nature, 310 620-623

Steın, R and Robert, C, 1986 Silıciclastıc sedıments at Sites 588, 590, and 591 
Neogene and Paleogene evolution in the southwest Pacific and Australian climate In J P Kennett, C C Von der Borch et al, Initıal Reports of the Deep Sea Drilling Project, Vol 90 U S Government Prınting Office, Washington, D C , pp 1437-1454 Woodruff, F , Savin, S M and Douglas, R G, 1981 Miocene stable isotope record A detalled deep Pacific Ocean study and its paleoclimatic implications Science, 212 $665-668$ 